\title{
REGULATING INDEPENDENT GAS PRODUCERS: THE FIRST AREA ATTEMPT
}

No longer is the Federal Power Commission the reluctant dragon that, in 1954, futilely argued its lack of jurisdiction over independent producers of natural gas. ${ }^{1}$ No longer is the Commission the paunchy and slowfooted governess who, in 1959, had to be reprimanded for letting her charges get "out of line." 2 Since that time the Commission has rejuvenated its approach, scrapping outmoded procedures and eliminating awesome docket backlogs. ${ }^{3}$ What was probably the outstanding example in the federal government of the breakdown of the administrative process ${ }^{4}$ has been substantially repaired. The Commission is literally pursuing its regulatory office to the bottoms of the wells. ${ }^{5}$

The innovation most necessary to the Commission's new facility of regulation, however, has yet to be passed upon by any court. The first area rate proceeding, establishing uniform ceiling and floor prices for natural gas sold in Texas' Permian Basin, ${ }^{6}$ is presently awaiting decision in the Court of Appeals for the Tenth Circuit. Permian, a massive evidentiary hearing, ${ }^{7}$ will in its final posture provide a model

1 See Phillips Petroleum Co. v. Wisconsin, 347 U.S. 672 (1954).

2 See Atlantic Ref. Co. v. Public Serv. Comm'n, 360 U.S. 378, 391 (1959) (Catco). The Catco case is discussed in greater detail in the text accompanying notes 29-31, 77-80 infra.

${ }^{3}$ See Freeman, Administrative Reform of FPC Natural Gas Regulation, Pub. Util. Fort., Feb. 18, 1965, p. 34, 36:

The commission in the past three years has completely cleared up the enormous backlog of pipeline rate cases, and in the process over $\$ 550$ million in pipeline refunds have been ordered and the city gate price of natural gas throughout the country has been reduced by a net amount of over $\$ 124$ million annually. In addition, settlements of producer increases have increased the total in refunds to well over $\$ 600$ million in the past three years. To my knowledge these sums are larger than any other regulatory agency has ordered returned to utility customers in a comparable period in the history of regullation.

See also Swidler, The Public Interest in Effective Natural Gas Regulation, Pub. Util. Fort., Oct. 8, 1964, p. 34. Examples of the procedural streamlining which has wrought these results are the requirement that parties seeking $\$ 4$ rate increases, see note 10 infra and accompanying text, must file all proof at once in a form reviewable by Staff and interested parties, periodic test audits of companies' books and the elimination of time-wasting internal procedures. See Freeman, supra at 37.

4 See notes 12, 33 infra and accompanying text.

5 In United Gas Improvement Co. v. Continental Oil Co., 381 U.S. 392 (1965), the Supreme Court upheld the Commission's asserted jurisdiction over a producer's sale to a pipeline of leases covering proven gas reserves. Thus the sale of an estate in land was held to be a sale of gas for resale in interstate commerce.

6 Area Rate Proceeding (Permian Basin Area), Utmity LAW REPoRT No. 689 (FPC Aug. 5, 1965).

7 Freeman, supra note 3 , at 37 . The examiner entertained some 30,000 pages of testimony. Francis, Area Price Regulation of Gas Producer Rates by the Federal Power Commission, 68 DICK. L. Rev. 237, 249 (1964). 
for the remaining in a series of area proceedings which, the Commission hopes, will ultimately stabilize the initial step of interstate gas commerce, the producer's sale to the pipeline.

The success of Permian depends to a great extent upon court acceptance of several novel regulatory devices. That these devices would be of deserved benefit to the consumer of natural gas is obvious. Equally obvious is the Supreme Court's sympathy with the Commission's regulatory problems; yet the Court will find it difficult to accept some of these innovations.

\section{History: The Roots of the Thicket}

Joinder in the endless debate whether the Natural Gas Act of 1938 should regulate in-state sales by independent producers for resale in interstate commerce ${ }^{8}$ is unnecessary-certainly the act was not well designed for that task. Section 7 of the act, to be sure, allows the Commission to withhold initial certification of a filed sales contract pending a determination that the rate serves "the public convenience

8 The debate is one fraught with political overtones. For example, after Phillips Petroleum Co. v. Wisconsin, 347 U.S. 672 (1954), had applied the act's provisions to independent producers, Congress passed a bill prohibiting the regulation of those producers. H.R. 6645, 84th Cong., 2d Sess. (1956). President Eisenhower, who strongly favored the bill, vetoed it only because

private persons, apparently representing only a very small segment of a great and vital industry, have been seeking to further their own interests by highly questionable activities. These include efforts that I deem to be so arrogant and so much in defiance of acceptable standards of propriety as to risk creating doubt among the American people concerning the integrity of the governmental processes ....

H.R. Doc. No. 342, 84th Cong., 2d Sess. (1956). The interplay of the various interest groups in this matter, both on and off the congressional floor, is discussed and excerpted in Read, MacDonald \& Fordeam, Cases on Legislation 559-636 (2d ed. 1959).

A similar bill had been passed as preventive medicine in 1950, Kerr-Harris Bill, H.R. 1758, 81st Cong., 2d Sess. (1950), and President Truman vetoed it. H.R. Doc. No. 555, 81st Cong., 2d Sess. 1-3 (1950). Senator Paul Douglas gives the following account of the aftermath:

[A]fter the completion of a thorough field survey, there was a change of opinion within the Commission and the majority took a stand against the Kerr

Bill. President Truman reappointed one of the members of the Commission who had taken a stand against the Kerr Bill. But the Senate refused to ratify this appointment.

Then there was a reverse switch inside the Commission which, with the appointment of a new member, changed a three to two majority for regulation into a four to one majority against regulation. Shortly afterwards the remaining member . . was denied reappointment by the White House after the change of administrations and resigned shortly before his term expired.

Douglas, The Case for the Consumer of Natural Gas, 44 GEo. L. REv. 566, 573 (1956).

The Permian hearing itself was not entirely free from such overtones:

Last week the big Texas petroleum interests brought in Governor John Connally, the President's own home state sidekick, to warn the Federal Power Commission that should it reduce the price of natural gas, the young and vibrant state of Texas itself might founder.

The New Republic, Feb. 20, 1965, p. 11. 
and necessity" ; ${ }^{9}$ such a provision is workable even in a world where certificate filings are so many and time consuming as to defy careful review without serious docket delay. But section 4, dealing with proposed rate increases under existing section 7 certificates, is inadequate on its face. That section gives the Commission only five months in which to hold a rate in abeyance while determining its propriety. ${ }^{10}$ Beyond this the only consumer safeguard is the Commission's power to condition the increase on the posting of a refund bond, to be used in the event that the increase is ultimately found improper. ${ }^{11}$ In practice this refund obligation has done little to benefit the consumer and has caused widespread confusion throughout the industry. Probably, too, the provision contributed to the increment of rates, as millions of dollars were held in escrow ${ }^{12}$ with no certainty as to their final disposition beyond the fact that the ultimate consumer was unlikely ever to see his money again.

But the failure of effective producer rate regulation must also be attributed to several other factors, one of which is the economic position of the independent producer. Concurrently with the post

9 Natural Gas Act $\$ \$ 7(c)$, (e), 52 Stat. 824 (1938), as amended, 15 U.S.C. $\S \S 717 f(c)$, (e) (1964):

(c) No natural-gas company ... shall engage in the transportation or sale of natural gas, subject to the jurisdiction of the Commission ... unless there is in force with respect to such natural-gas company a certificate of public convenience and necessity ... .

(e) . . [A] certificate shall be issued to any qualified applicant therefor $\therefore$ if it is found that the applicant is able and willing properly . . to perform the service proposed and to conform to the provisions of this chapter and the requirements, rules, and regulations of the Commission thereunder, and that the proposed service . . . is or will be required by the present or future public convenience and necessity; otherwise such application shall be denied.

(1964):

10 Natural Gas Act $\S 4$ (d), (e), 52 Stat. 822 (1938), 15 U.S.C. $\$ \S 717 c(d)$, (e)

(d) . . [N]o change shall be made . . except after thirty days' notice to the Commission and to the public. . . .

(e) Whenever any such new schedule is filed the Commission shall have authority . . . to enter upon a hearing concerning the lawfulness of such rate ... [and] pending such hearing and the decision thereon, the Commission . . may suspend the operation of such schedule and defer the use of such rate . . . but not for a longer period than five months beyond the time when it would otherwise go into effect. . . . Where increased rates . . . are thus made effective, the Commission may . . . require the natural-gas company to furnish a bond . . . to refund any amounts ordered by the Commission ... .

11 Ibid.

12 See, e.g., Swidler, The Challenge of Natural Gas Regulation, in AMrricaN Bar Ass'n, 1962-63 Proceedings of the Section of Mineral and Natural ReSOURCES LAW 2-3:

We have still pending before the Commission one pipeline rate case in which sums collected subject to refund over a period of years approaches [sic] the staggering figure of $\$ 400$ million, and the amount increases at the rate of $\$ 9$ million a month.

Compare note 3 supra. 
World War II explosion in demand for natural gas, ${ }^{13}$ various decisions of the Supreme Court made it advantageous for the gas pipelines to deal with the as yet unregulated independent producers, rather than with their own affiliates. ${ }^{14}$ Meanwhile, the FPC requirement that pipelines obtain access to reserves adequate to meet demands of the distant future ${ }^{15}$ insured that demand would outstrip supply. Independent producers were thus able to insist on higher prices ${ }^{16}$ and devices such as escalation and most favored nation clauses, under which the producer was guaranteed a rate equal to the highest paid any producer in the area. For the first time pipelines felt forced to compete with each other in various parts of the country. Frequently, to gain purchasing access to a producing area, they applied "blockbusting" techniques, agreeing to purchase at rates greatly in excess of those currently paid in the area. ${ }^{17}$ The most favored nation clauses would then, of course, correspondingly "trigger" all rates in the area. A final frustrating element lay in the then impossibility of directing a search for gas alone, rather than in combination with oil.18 Since such combined deposits yielded, on the average, far more oil than gas, and since oil was in earlier times a more marketable commodity, ${ }^{19}$ increased gas prices could not spur the search for new gas in such a way as to allow the market to adjust itself at lower competitive rates. The extent of searching, drilling and production depended upon the market for oil.

In time the production field came to be dominated by a number of giant producers, while a mass of relatively tiny independents rode

13 In earlier times, when oil was the dominant interest of the driller, natural gas was often flared off at the wellhead, because the driller considered it worthless and, indeed, a liability. The explosion in demand for gas is discussed in Connole, General Considerations: A Nation's Natural-Gas Pains, 44 GEo. L.J. 555-56 (1956) ; Cram, Introduction to the Problents of Developing Adequate Supplies of Natural Gas, in International OII \& Gas Educational Center, Economitcs of the Gas Industry 1-3 (1962); LeBoeuf, Chaos in the Natural-Gas Industry from the Distributor Viezepoint, 44 GEo. L.J. 607, 608 (1956).

14 See Interstate Natural Gas Co. v. FPC, 331 U.S. 682 (1947) ; Colorado Interstate Gas Co. v. FPC, 324 U.S. 581 (1945); FPC v. Hope Natural Gas Co., 320 U.S. 591 (1944).

15 Douglas, mipra note 8, at 584; cf. Netschert, Economic Aspects of Natural Gas Supply, in International On \& Gas Educational Center, op. cit. supra note 13, at 27,67 .

${ }^{16}$ See Permian Area Rates, No. AR61-1, FPC, Sept. 17, 1964, p. 18 (Examiner's decision) :

Between 1947 and 1960 the average price paid by pipelines for gas trebled,

from 4.95 cents to 15.61 cents. Even after adjusting for changes in the pur-

chasing power of the dollar, prices in 1960 were some 2.3 times their 1947 level.

Accord, Netschert, supra note 15 , at 67. decision).

17 Permian Area Rates, No. AR61-1, FPC, Sept. 17, 1964, pp. $20-22$ (Examiner's

18 FPC v. Hope Natural Gas Co., 320 U.S. 591, 649 (1944) (Jackson, J., dissenting); see Area Rate Proceeding (Permian Basin Area), UtIITY LAw RePorr No. 689 (FPC Aug. 5, 1965).

${ }^{19} \mathrm{Cf}$. Douglas, supra note 8 , at 590-91; Netschert, supra note 15 , at 37 ; authorities cited note 13 supra. 
their bargaining coattails. ${ }^{20}$ The pipelines, having heavy investments in costly apparatus, ${ }^{21}$ were often willing to meet increased rate demands rather than seek new supply sources and lay new lines. Several other factors made these pipelines poor bargaining agents for the ultimate consumer. The original field price of gas is but a component of its ultimate consumer cost; so a producer rate increase might not be strongly felt by either the consumer or the distributor. Further, the pipelines had gas monopolies of their consumer markets. ${ }^{22}$ Finally, the homeowner's costs in changing from one fuel system to another would probably prohibit his taking his business elsewhere. The pipeline could readily pass its cost increases down to the final buyer; a monopoly-holding middleman insulated the seller from the consumer.

When, in Phillips Petroleum Co. v. Wisconsin, ${ }^{23}$ independent producers did come under FPC regulation, a reluctant Commission did not question the validity of most favored nation clauses. The inevitable result was a deluge of rate increase filings from the many producers. ${ }^{24}$ This alone might have defeated any hope of efficient producer regulation. That defeat was made certain by the Commission's attempt to judge rate filings case by case, by the cost-ofservice standard. ${ }^{25}$

Mr. Justice Jackson stated what should have been the obvious when he faulted the individual cost-of-service standard as a gas producer yardstick. ${ }^{26}$ The producer of the forties and fifties, unable to direct a gas search efficiently, was a gambler whose costs of exploration and drilling bore little if any relation to the actual value of his product. Further, the individual cost-of-service standard seems

${ }^{20} \mathrm{Cf}$. text accompanying notes 88,95 infra.

21 The cost of pipeline has been estimated at from $\$ 40,000$ to $\$ 100,000$ per mile. Douglas, supra note 8, at 577. In Atlantic Ref. Co. v. Public Serv. Comm'n, 360 U.S. 378, 383 (1959) (Catco), which dealt with offshore oil finds, the Supreme Court noted that in reliance on the sale, the pipeline interest had built installations at an estimated cost of $\$ 85,000,000$.

22 See Douglas, supra note 8, at 583. Compare LeBoeuf, supra note 13, at 610-11. 23347 U.S. 672 (1954).

24 Cf. note 33 infra.

25 It is difficult to place blame squarely upon either the approach or the way in which it was effected. Compare note 26 infra, with Netschert, Natural Gas Price Regulation: The Consumer Viewpoint, Pub. Util. Fort., Oct. 8, 1964, p. 63, 68:

One of the major issues here is the relative workability of the individual company versis the area rate approach. As I see it, both are workable; and as $I$ understand the motivation of the Federal Power Commission in abandoning the individual company approach, it was not because regulation could not be carried on, but because it had not been. The mountainous backlog was there, the problem of staleness was acute, and something had to be done en masse to get current again.

One case clearly demonstrating the plethora of issues that must be (or were) entertained in an individual cost-of-service case is Pan Am. Petroleum Corp., 19 F.P.C. 463,467 (1958).

26 The service one renders to society in the gas business is measured by what he gets out of the ground, not by what he puts into it, and there is little more relation between the investment and the results than in a game of poker. FPC v. Hope Natural Gas Co., 320 U.S. 591, 649 (1944) (Jackson, J., dissenting). 
uniquely suited to multiply the woes of an overworked agency; the standard brings into question the producer's entire financial structure for the most incidental of contested sales. ${ }^{27}$ Moreover, such a standard probably encourages evidentiary verbosity; both sides will throw in every conceivable shred of data in an attempt to color the total cost picture. ${ }^{28}$

Ultimately the Commission threw up its hands and attempted to abdicate. Faced with a large sale at a rate which would trigger large increases throughout the South Louisiana area, it accepted the producer's rate rather than risk the loss of the gas to the public. The Commission construed section 7's "public convenience and necessity" to require, primarily, that a large reserve of gas be maintained for the interstate consumer. ${ }^{29}$ The Third Circuit's reversal ${ }^{30}$ was affirmed by the Supreme Court on the theory that the Commission had a duty to avoid insupportable price increases.

Where the proposed price is not in keeping with the public interest because it is out of line or because its approval might result in a triggering of general price rises or an increase in the applicant's existing rates by reason of "favored nation" clauses or otherwise, the Commission in the exercise of its discretion might attach such conditions as it believes necessary.

This is not an encroachment upon the initial rate-making privileges allowed natural gas companies under the Act . . . but merely the exercise of that duty imposed on the Commission to protect the public interest in determining whether the issuance of the certificate is required by the public convenience and necessity ..... ${ }^{31}$

It is not surprising, in light of the docket backlog, that it was not until 1960 that the Commission got around to dealing with that particular group of producers which the Supreme Court had first ordered it to regulate in $1954 .^{32}$ At last the Commission acknowledged

27 See, e.g., Pan Am. Petroleum Corp., 19 F.P.C. 463 (1958).

28 See Swidler, supra note 12 , at 3.

29 Continental Oil Co., 17 F.P.C. $880,881-82$ (1957). The producers were before the Commission for the third time, having twice been offered temporary or conditioned certificates and rejected them. The precise question in the case was whether the Commission should insist on its plan of issuing an initial certificate at the price it thought proper, while allowing the producers to increase their rate twenty-four hours later, subject to the "just and reasonable" refund conditions of $\$ 4$, or whether the $\$ 7$ certificate should be given at the high rate, subject only to a Commission-initiated hearing on the rate's "justness" and "reasonableness" under $\$ 5$ of the act, 52 Stat. 822 (1938), 15 U.S.C. $\$ 717 \mathrm{~d}$ (1964), quoted at note 80 infra. In the latter event, which is what occurred, the Commission would have no refund power pending its $\$ 5$ determination. 30 Public Serv. Comm'n v. FPC, 257 F.2d 717 (3d Cir. 1958).

31 Atlantic Ref. Co. v. Public Serv. Comm'n, 360 U.S. 378, 391-92 (1959) (Catco). (Emphasis added.)

32 Phillips Petroleum Co., 24 F.P.C. 537 (1960). 
the failure of its case-by-case cost-of-service approach, cataloging its woes in detail. ${ }^{33}$ Its remedy was to divide the producing gas fields into several areas and to launch area rate proceedings which would set a proper rate for gas sold in each. ${ }^{34}$ Permian was the first such proceeding.

\section{The Two-Price System: Time and Cost Averaging}

The Permian "just and reasonable rates" were ultimately bottomed in "composite costs" of gas production..$^{35}$ The producers' costs of finding, developing and providing service from their wells were analyzed and averaged. ${ }^{36}$ Court approval of the concept of average cost-based ratemaking seems assured by both prior decisions and logic; ${ }^{37}$ the inefficient producer should not have the right to sell his gas at a profit to the detriment of the consumer. ${ }^{38}$ Furthermore, the Commission seems to have taken adequate precautions that no pro-

33 Id. at $545-46$ :

An illustration of the administrative impossibility of separate determinations for all producers' rates is found in the fact that there are 3,372 independent producers with rates on file with this Commission. The producers have on file with us 11,091 rate schedules and 33,231 supplements to these schedules. Currently, 570 of these producers are involved in 3,278 producer rate increase filings now under suspension and awaiting hearings and decisions. The number of completions of independent producer rate cases per man-year during the first 6 years following the Phillips decision indicate that nearly 13 years would be required for our present staff to dispose of the 2,313 cases pending on July 1,1960 . Within this 13-year period an additional estimated 6,500 cases would have been received.

Thus, if our present staff were immediately tripled, and if all new employees would be as competent as those we now have, we would not reach a current status in our independent producer rate work until 2043 A.D.eighty-two and one-half years from now. ... If we increased our efficiency one thousand percent, we would achieve current status in 1968-eight and two-tenths years from now.

The rejection of individual cost-of-service regulation was upheld in Wisconsin $v$. FPC, 373 U.S. 294, 310 (1963).

34 Statement of General Policy No. 61-1, 24 F.P.C. 818 (1960). Details of the Statement's execution have been amended several times. E.g., 24 F.P.C. 902 (1960); 24 F.P.C. 1107 (1960). The Permian Basin, actually, is only one of several areas being regulated in the Permian proceeding. Thus references in text to the Permian Basin should be taken to mean that and all other areas taken in by the proceeding.

35 Area Rate Proceeding (Permian Basin Area), Utrlity Law RePoRt No. 689, at 35-39 (FPC Aug. 5, 1965).

$36 I d$. at 78-80. The cost of gas already brought to the market was determined with reference only to the producers' costs in the Permian area. Id. at 80-81. The New Gas price, discussed herein, was based upon national cost estimates. While the Commission recognized that production costs of New Gas might vary sufficiently in some areas to justify different treatment, no such variance was felt to be necessary in the Permian Basin price. Id. at 38.

37 See Wisconsin v. FPC, 373 U.S. 294 (1963) ; FPC v. Hope Natural Gas Co., 320 U.S. 591, 602 (1944) ; Note, 75 HARv. L. Rev. 549, 566-68 (1962).

38 The Supreme Court has stated more than once that the inefficient or unproductive producer has no constitutional or statutory right to be guaranteed a profit by virtue of his regulated status. E.g., Acker v. United States, 298 U.S. 426, 431 (1936): "[R] egulation cannot be frustrated by a requirement that the rate be made to compensate extravagant or unnecessary costs . . "Compare the dissenting opinion of Mr. Justice Jackson in FPC v. Hope Natural Gas Co., supra note 37, at 649. 
ducer will be forced to continue selling gas at a confiscatory-less than individual costs-rate. ${ }^{39}$

But gas sale contracts, because of the nature of gas production and the FPC reserve requirements, are novel in their longevity; ${ }^{40}$ thus the Commission was setting a just and reasonable rate for gas, flowing in 1960 , which had originally been dedicated to commerce as early as 1940.41 At the same time, it was setting a rate for gas to be dedicated in the future ${ }^{42}$ which had to be high enough to insure the continued bringing of gas to the interstate market. ${ }^{43}$ Since the industry had recently developed "directionality"- the ability to direct a search for gas alone, rather than in combination with oil ${ }^{44}$-a high profit return could encourage the finding of gas. For these reasons the Commission promulgated a two-price system, one price being applicable only to "Gas Well Gas" found after January 1, 1961.45 The rate for this gas, found in a well whose primary function is to provide gas alone, was based upon the estimated costs of originally bringing gas to the market place after 1960.46 A "Flowing Gas" rate, substantially lower, was to be paid for gas originally dedicated before $1961,{ }^{47}$ as well as for gas, whenever dedicated, produced from wells whose primary function is to provide oil. ${ }^{48}$

In general, the idea of making rates depend upon the time of finding is a good one; the consumer should not pay today's prices for gas produced at yesterday's costs. Moreover, the goal of encouraging gas production would not be served by paying a premium to the oil producer who finds gas at the bottom of his well, available to the consumer only in proportion to the market for oil. ${ }^{49}$ But the Commission's method of setting the Flowing Gas rate gives rise to ir-

39 The Commission will, in such cases, allow either abandonment or a rate increase if warranted. See note 150 infra and accompanying text.

40 In this aspect the natural gas situation differs radically from those industries as to which average rate regulation has been upheld. E.g., New York v. United States, 331 U.S. 284 (1947) (railroad rates) ; Sunshine Anthracite Coal Co. v. Adkins, 310 U.S. 381 (1940) (coal) ; United States v. Corrick, 298 U.S. 435 (1936) (stockyards); Nebbia v. New York, 291 U.S. 502 (1934) (milk).

41 Permian Area Rates, No. AR61-1, FPC, Sept. 17, 1964, App. C at 34a-36a (Examiner's decision).

42 Area Rate Proceeding (Permian Basin Area), Utility Law Report No. 689, at 1 (FPC Aug. 5, 1965).

43 See $i d$. at $30-32,56$.

$44 I d$. at 28.

45 Id. at 33-35.

$46 I d$. at 34. This seems to have been tantamount to applying 1960 costs across the board, since the Commission adverted to its finding that costs have been stable since 1958. See text accompanying note 66 infra.

47 Area Rate Proceeding (Permian Basin Area), UtwIty LAw RepoRt No. 689, at 29-32, 78-80 (FPC Aug. 5, 1965).

48 Id. at 71-74.

19 See $i d$. at $70-71,76$. 
rational differences in the profit returns of various Permian Basin producers of average efficiency and, if followed in other area proceedings, will probably cause similar differences among the different gas producing areas.

The Gas Well Gas rate (New Gas rate) was determined by estimating the average costs of producing gas found in 1960, while the Flowing Gas rate (Old Gas rate) was set on the basis of the "composite historical costs" of all gas flowing in 1960.50 The Commission, on the basis of these composite costs, determined that on the average, Flowing Gas had been produced at $84 \%$ of the cost of 1960-dedicated gas. ${ }^{51}$ A discussion of this finding, or of the propriety of the Commission's decision that both Old and New Gas rates should include a profit return of $12 \%$ on costs, ${ }^{52}$ is beyond the scope of this Comment. The quarrel is with the finding of costs.

Evidence entertained by the hearing examiner indicated that the costs of producing natural gas have risen sharply since at least $1947 .{ }^{63}$ Since these costs are typically capitalized by the producer over the life of his production contract, ${ }^{54}$ his present cost of delivering gas to the pipeline will vary substantially depending upon the year in which he originally found his well. ${ }^{55}$ If, then, a determination of proper rates utilizes the average production costs of all gas found between 1947 and 1960, as Permian's does, two things must follow: the average 1947 producer will be credited with costs radically higher, and the 1960 producer with costs substantially lower, than those he actually incurred. Furthermore, these capitalized cost attributions will exert substantial downward or upward pressure on the final rate itself, since historical (capitalized) costs make up over two-thirds of the Permian rate base upon which return is computed. ${ }^{56}$ Thus, if the 1948 producer's capitalized costs are actually $62.4 \%$, rather than $84 \%$, of 1960 original capitalized costs, he is being credited with a $21.6 \%$ "bonus" in terms of those 1960 costs. Reflected in a rate based on total production

50 Id. at 78-80. The term "New Gas" applies to Gas Well Gas produced since 1961 ; "Old Gas" is synonymous with "Flowing Gas" and refers to all gas originally dedicated prior to the inception of the Permian hearing in 1961. The "Old Gas rate," or "Flowing Gas rate," however, is applicable to all oil well gas dedicated subsequent to 1961. See notes 45, 47-48 supra and accompanying text.

51 Area Rate Proceeding (Permian Basin Area), UtILIty Law Report No. 689, at 91 (FPC Aug. 5, 1965).

52 The problem is an obscure one. The various parties had recommended returns of from 9.5 to $18 \%$. Id. at 55-66.

53 Permian Area Rates, No. AR61-1, FPC, Sept. 17, 1964, pp. 78-81, App. C at 34a-42a (Examiner's decision); see Table I, p. 115 infra.

$54 C f$. Area Rate Proceeding (Permian Basin Area), Utrlity LAw Report No. 689, at 37-38 (FPC Aug. 5, 1965). Compare id. at 90.

55 Table II, p. 115 infra, illustrates the hearing examiner's finding that a substantial percentage of the gas flowing in 1960 was in fact found in the earlier low cost years.

${ }^{56}$ Compare the following details of the New and Flowing Gas rates as set by the Commission: 
costs, this bonus would add almost $15 \%$ to the total production costs rate base. ${ }^{57}$ To the same effect, if the 1959 producer is assumed to have incurred actual capitalized costs of about $91.8 \%$ of 1960 capitalized costs, then about $7.8 \%$ of his actual capitalized cost is not being attributed to him, reflecting a $5.2 \%$ diminution of his total rate base and, correspondingly, his profit. Results such as these are quite a different matter from a holding merely that the inefficient producer should not expect to profit; rather they say that the quantum of profit to which the producer of average efficiency is entitled depends upon when his gas was found. Granting that the producer, being a gambler, should not be paid more for his product than is the producer of average efficiency, there appears to be little defense for a rate-setting standard which forces the average 1960 producer to maintain a higher level of efficiency than the 1947 producer in order to earn a comparable return.

One answer to this argument would be impossibility. If the annual costs could not be found, or were so difficult of ascertainment as to render the Permian proceeding virtually interminable, there would be little sense in ordering the Commission to find them. It is to this argument that the Commission turned. "The alternative of a separate cost study for each of the years . . . would have presented

\begin{tabular}{|c|c|c|}
\hline Erhloration and Domplatmont Costs & New Gas & Flowing Gas \\
\hline $\begin{array}{l}\text { Dry Holes } \\
\text { Other Exploratory Costs }\end{array}$ & $\begin{array}{l}\$ 1.42 \\
1.59\end{array}$ & $\begin{array}{l}\$ 1.42 \\
1.59\end{array}$ \\
\hline $\begin{array}{l}\text { Adjustment for Exploration in } \\
\text { Excess of Production } \\
\text { Production Operating Expense } \\
\text { Net Liquid Credit } \\
\text { Regulatatory Expense } \\
\text { Depletion, Depreciation and Anorti- }\end{array}$ & $\begin{array}{c}1.11 \\
2.70 \\
(3.10) \\
.14\end{array}$ & $\begin{array}{c}1.11 \\
2.70 \\
(3.10) \\
.14\end{array}$ \\
\hline $\begin{array}{l}\text { zation of Production lnvestment Costs } \\
\text { Successful Well Costs } \\
\text { Lease Acquisition Costs } \\
\text { Cost of Other Production Facilities }\end{array}$ & $\begin{array}{r}2.88 \\
.76 \\
.31\end{array}$ & $\begin{array}{r}2.42 \\
.64 \\
.26\end{array}$ \\
\hline $\begin{array}{l}\text { Return on Prodiction Investment } \\
\text { (at 12\%) } \\
\text { Return on Working Capital }\end{array}$ & $\begin{array}{r}5.21 \\
.35\end{array}$ & $\begin{array}{r}4.38 \\
.35\end{array}$ \\
\hline $\begin{array}{l}\text { Subtotal } \\
\text { Royalty at } 12.5 \% \\
\text { Production Taxes }\end{array}$ & $\begin{array}{r}\$ 13.37 \\
2.05 \\
1.01\end{array}$ & $\begin{array}{r}\$ 11.91 \\
1.83 \\
.90\end{array}$ \\
\hline Total & $\$ 16.43$ & $\$ 14.64$ \\
\hline
\end{tabular}

Area Rate Proceeding (Permian Basin Area), Utility Law Report No. 689, at 40, 93 (FPC Aug. 5. 1965). The royalty and production components have not been included in the tabulation, since these items, though cost-related, are only estimates of what the producer will pay to others on the basis of his actual rate. These items thus cast no reflection upon the compensatoriness of the rates. Each of the varying items is, in the case of Flowing Gas, equal to $84 \%$ of the corresponding New Gas item, rounded off to the nearest $1 / 100$ th of a cent.

57 See the chart in note 56 supra.

58 These hypothetical producer costs are the ones most charitable to the position that costs have not climbed radically, both being taken from the estimate showing the less steep increment in costs. See Table I, p. 115 infra. 
an almost impossible task. At best it would have prolonged this proceeding greatly." 59

But it is difficult to reconcile this conclusion with the facts. The hearing examiner, while he had not specifically relied upon year-byyear costs of finding gas, did make extensive use of the statistical evidence set out in Table I below. ${ }^{60}$ The Commission, too, disclaimed reliance upon these tables, relying instead on the Staff's "composite historical costs index." 61 While each of these studies reached a different set of conclusions as to the precise cost of finding gas in a given year, all showed substantial increments in finding costs between 1947 and $1960 .^{62}$ Each broke these increments into year-by-year steps.

The Commission's decision can, of course, be defended on the ground that the various exhibits did yield greatly varying conclusions as to the costs of production in specific years; ${ }^{63}$ thus all of the annual costs evidence might be assailed as inherently unreliable. But the Commission did rely upon the evidence and concluded that the Staff's and the examiner's cost finding methods yielded similar results. ${ }^{64}$ Instead of relying upon the annual data, the Commission lumped them all together and estimated the average costs. Thus, if the evidence was unreliable, the Commission compounded its unreliability.

The related argument, that a precise determination of these annual costs would have taken too much time, must also fail. If the annual costs evidence did nothing else, it pointed out the probability that costs had risen over the years; the Commission had a duty to plumb that issue. Annual costs evidence had already been entertained from various opposing parties, who seemed generally to agree that costs had risen precipitously, ${ }^{65}$ and it is not likely that making findings on that evidence would, in the context of a four and one-half year proceeding, have caused much relative delay. Finally, it seems obvious in context that even a series of rough guesses at annual costs would have come closer to the goal of just and reasonable rates than would a rigid finding of one cost, applied to a span of years over which costs have obviously varied substantially.

The Commission, however, concluded that such annual findings would not make much difference in the rates ultimately set:

59 Area Rate Proceeding (Permian Basin Area), Utility LAw Report No. 689, at 80 (FPC Aug. 5, 1965).

60 Permian Area Rates, No. AR61-1, FPC, Sept. 17, 1964, pp. 78-81, App. C at $34 a-42 a$ (Examiner's decision). Table $I$ is at p. 115 infra.

61 Area Rate Proceeding (Permian Basin Area), Utmity Law Report No. 689, at 79 (FPC Aug. 5, 1965).

62 Ibid.; Table I, p. 115 infra.

63 See Tables I \& II, p. 115 infra.

64 Area Rate Proceeding (Permian Basin Area), Utility Law Report No. 689, at 79, 89-93 (FPC Aug. 5, 1965).

65 Ibid. While this testimony was not, of course, conclusive, it is noteworthy that absolutely no evidence was submitted in refutation of the premise that costs had so risen. 
The basic evidence utilized in Staff's composite cost presentation was collected for 1960 . In addition, certain trend information was obtained for prior years. These and related data reveal that the 1960 level of costs is fairly representative of the costs during the three year period ending in 1960. While unit costs were somewhat lower in the earlier years, they leveled off in 1958 and so far as the evidence shows have never since exceeded this level. The 1960 test year is, therefore, typical of current and future costs of the flowing gas and it is also more than fair to the producers as a basis for just and reasonable prices for the prior years when costs were slightly lower. [A finding of average annual costs] . . was not justified since little gas was selling in the 1954-57 period at prices even approaching our ceiling as established herein. ${ }^{66}$

Two problems arise: first, the Commission makes much of the fact that costs have not risen substantially between 1958 and 1960 or, perhaps, the present. But the $1958-1960$ producer is not being allowed a rate based on average 1958-1960 costs; he is receiving a rate based on average 1947-1960 costs-the Flowing Gas costs. Thus the 1958-1960 figures, far from aiding the Commission's position as to the propriety of the Flowing Gas rate, weaken it by indicating that the 1958 producer probably incurred costs roughly equal to those of the producer enjoying the New Gas rate. Yet the earlier producer's rate is based upon only $84 \%$ of the costs both presumably incurred. Perhaps, on the other hand, the Commission is referring only to Flowing Gas costs in making its statement that costs have not increased substantially since 1958 . If so, the statement is meaningless. Obviously composite historical costs will increase only in small proportion to the amount that current costs increase; each annual increment will be diluted in the stewpot of historical costs.

Second, the Commission, for some inscrutable reason, seems most interested in showing that earlier finders of gas will not be injured by Permian's Flowing Gas rate. Of course they will not; it is the latter day finder, as well as the consumer, who will suffer. To the extent that the annual costs evidence is correct, it shows that the early producer will get a windfall under the Permian scheme. If the rate is still high enough to compensate the 1960 producer, that windfall is enormous, and the consumer will suffer accordingly. If it is, in its totality, fair to the consumer, the latter day producer is being robbed.

A variant of the historical cost problem is only theoretical at this early date: other area proceedings have begun since Permian's in-

66 Area Rate Proceeding (Permian Basin Area), Utmity LAw Report No. 689, at 80 (FPC Aug. 5, 1965). (Emphasis added.) 
ception. South Louisiana, ${ }^{67}$ like Permian, uses 1960 as its "test" year. But two other proceedings, Hugoton-Anadarko and Texas Gulf Coast, ${ }^{68}$ will be considering 1962 costs as determinative. The Commission states that costs have remained, and will remain, relatively stable after 1958 and this, if true, should insure that the Hugoton New Gas producer will not attract a rate unconscionably higher than that received by the Permian Basin producer of New Gas. But this is not the case as to Flowing Gas. Even if contemporary costs remain precisely the same, there will be more of these recent costs figured into the Commission's grand equation than there were in Permian. To like effect, the 1962 test year will probably reflect fewer instances of Flowing Gas found before 1960 . The result will be that the Hugoton producer of gas found in 1960 or earlier will have generally higher costs figured into his average historical cost picture-despite actual costs that are presumably identical - than will the similarly situated Permian Basin producer.

The final defect of the Commission's use of time-averaged costs is the sharp discrepancy it produces between 1960 and 1961 gas rates. If this difference were based upon actual cost differentials, there would of course be no complaint; that is not this case. Here the 1960 gas finder's costs have been found and applied to the 1961 finder. The 1960 finder himself, meanwhile, is given the average of his own and his predecessors' costs. To the extent that there is a cost variance between 1960 and 1961 gas some rate difference would be justifiable, even though each rate was based on the costs of a prior year, provided the rate of cost increase was relatively uniform across the years. Such a system would serve only to lessen the profit return, uniformly, to the extent that contemporary costs increased. That, again, is not this case; no one claims that the 1961 producer's finding costs are so far above those of 1960 as to justify the Permian difference. To a certain extent, the difference between 1960 and 1961 rates could also be justified on the ground that the New Gas rate is to be in effect for several years, and that it has therefore been set sufficiently high to absorb anticipated cost increases without injuring the rate's compensatoriness. But such a rationale, like that involved in setting the Flowing Gas rate, can carry only so far. To the extent that it provides a substantial windfall for the 1961 producer, it should not stand. In any case, the Commission anticipates no such annual cost increments in the immediate future. ${ }^{69}$

Finally, since 1961 was about the time when the gas producers, for the first time, were able effectively to direct a search for Gas Well

67 Area Rate Proceeding (South Louisiana Area), 25 F.P.C. 942 (1961).

68 Area Rate Proceeding (Hugoton-Anadarko \& Texas Gulf Coast Areas), 30 F.P.C. 1354 (1963).

69 Area Rate Proceeding (Permian Basin Area), Utmity Law RepoRt No. 689, at 80, 109 (FPC Aug. 5, 1965). 
Gas, ${ }^{70}$ it might be argued that the high rate is justified as an inducement to producers to find the gas required in an expanding market, a rationale inapplicable to gas already flowing. Indeed, this is the Commission's primary rationale for the two-price system:

The touchstone of the presiding examiner's decision is his conclusion that the industry is increasingly becoming able to direct its exploration efforts toward finding new gaswell gas as distinguished from finding gas as a by-product in the search for oil. This new documented ability of the industry to channel its exploration investment toward either gas or oil serves as the basis for a pricing system, which we here adopt, that will make use of the economic drive of the industry to bring needed gas supplies to consumers at the lowest reasonable price. ${ }^{71}$

But if the New Gas rate is really to be an incentive to exploration, why should it apply to gas that has already been found and dedicated to interstate commerce? The Commission gives the following reasons: that 1960 was the costs test year; that 1961 marks, more or less, the beginning of search directionality; and that the Commission's 1960 adoption of the area rate approach somehow induced post-1960 producers to anticipate a rate that included a bounty component for finding Gas Well Gas. ${ }^{72}$

The fact that 1960 was the costs test year is of no help to this disposition; all that factor does is turn us back to the fact that the rate is cost-based and that the division between 1960 and 1961 prices is huge. While it rationalizes the 1961 application of the New Gas rate, it provides no excuse for the 1960-1961 gap. The second reason given, that search directionality first became possible around 1961, would also seem irrelevant. The post-1960, pre-1966 producers have already dedicated their gas to commerce; it is of course impossible to induce a man to seek that which he has already found. These Permian producers are being paid, not for what they produced, but for the fact that they were looking for it when they found it. It would not seem to be the function of a rate-setting agency to reward or punish its subjects on the basis of their assumed state of mind, regardless of their product's quality. Finally, there is the alleged producer "reliance" upon an incentive component's being included in the Permian Basin rates. This is simply not true. Both the Commission and the general public were well aware that the area rate proceedings were designed to halt runaway rate increases, not to establish new reward systems based upon the fact of search directionality. ${ }^{73}$

$70 I d$. at 28.

71 lbid.

72 Id. at $34-35$.

73 Id. at 31. 
The foregoing does not mean that the rates for 1961 gas are necessarily excessive but shows only that the Commission's explanation of the New Gas rate provides no defense for the great gap between 1960 and 1961 rates. A system by which rates are set on the basis of costs in the year of discovery, or even on the basis of any group of years among which the cost differences were not overly large, would solve this problem as well as the other problems noted above. ${ }^{74}$

Permian's rate setting leaves much to be desired. A different question is whether a reviewing court will find this pricing system to be within the Commission's discretion. To the earlier decisions, stating that the Commission is not bound to any particular standard in setting rates, ${ }^{75}$ must be added the holding in United Gas Improvement Co. v. Callery Properties, Inc. ${ }^{76}$ That case grew out of the Commission's refusal, pending the determination of area rates, to hear costs evidence in individual rate hearings. Instead the Commission applied "guideline" prices which had been promulgated in accordance with the Supreme Court's 1959 order that it not allow rates to get "out of line." 77 Callery held that the Commission was not bound to entertain this cost evidence which the producers sought to introduce. Callery relied substantially on Catco, ${ }^{78}$ the 1959 "out-of-line" case.

We think the Commission acted lawfully and responsibly in line with . . . CATCO ... . where we held that it need not permit gas to be sold in the interstate market at the producer's contract price, pending determination of just and reasonable rates under $\S 5$. . . Rather, we held that there is ample power under $\S 7(\mathrm{e})$, to attach appropriate protective conditions. ${ }^{79}$

Catco declared that the "public convenience and necessity" standard of the original certification section, section 7 , implied a duty to see that the rates would not offend the "just and reasonable" standards of sections 4 and $5 .^{80}$ Specifically, the case held that the Commission

74 Such a disposition should solve the problems noted as to rate differences among areas, see notes 67-68 supra and accompanying text, as well as among producers in a given area. Thus a proceeding like Hugoton, which uses 1962 as its test year, could set new annual finding rates only for the years since 1960 . It would also seem that such an approach would greatly simplify the task of the Commission in subsequent area proceedings, since it could merely apply those annual costs already found with appropriate local adjustments.

75 E.g., FPC v. Hope Natural Gas Co., 320 U.S. 591, 602 (1944).

76382 U.S. 223 (1965).

77 Atlantic Ref. Co. v. Public Serv. Comm'n, 360 U.S. 378, 391 (1959) (Catco). 78 Ibid.

79382 U.S. at 227.

80 Section 4's provisions are given at note 10 supra. Section 5 (a) provides for Commission investigation and correction of existing rates:

Whenever the Commission, after a hearing had upon its own motion or upon complaint . . shall find that any rate, charge, or classification demanded, observed, charged or collected by any natural gas company ... or 
had the power to condition section 7 rates upon the posting of refund bonds pending the determination of a just and reasonable rate in a Commission-initiated section 5 investigation.

Obviously Callery goes a long step further, for there the initial section 7 rate was the "in-line" rate, the rate at which uncontested sales contracts were presently operating, ${ }^{81}$ and the producers had sought to attain a higher "out-of-line" rate subject to a Catco-type refund condition. In this context the consumer is protected, but there is no safeguard for the producer against the "in-line" rate's ultimately being found too low. ${ }^{82}$ But both cases make much of the fact that the "condition" imposed is to be operant only "pending determination of just and reasonable rates under $\S 5$." $\$ 3$ Both decisions were premised on the fact that section 5 proceedings, in which the Commission can investigate an operant rate and, if it is found too high, establish a new just and reasonable rate, are occasions of "inordinate delay" during which the consumer could not be adequately protected. ${ }^{84}$

But the area rate proceedings are themselves section 5 proceedings. ${ }^{85}$ In fact, the pending South Louisiana area proceeding ${ }^{86}$ seems to be precisely that section 5 determination of just and reasonable rates abiding which the Callery "in-line" rates were sustained. ${ }^{87}$ Callery, for sound administrative reasons, allowed the Commission to delay ascertaining with precision the just and reasonable rate; it did not expunge the producer's or the public's ultimate right to such an ascertainment.

The time-averaging theory of Permian pricing has a built-in bias in favor of earlier gas finders and against later ones. The resulting

that any rule, regulation, practice, or contract affecting such rate, charge, or classification is unjust, unreasonable, unduly discriminatory, or preferential, the Commission shall determine the just and reasonable rate . . . to be thereafter observed and in force . . . .

Natural Gas Act $\$ 5(a), 52$ Stat. 823 (1938), 15 U.S.C. $\$ 717$ d(a) (1964). See text accompanying note 84 infra.

81382 U.S. at 227 . The rule that gas should be introduced only at rates no higher than those of Flowing Gas already certificated under $\$ 7$ is the "in-line" doctrine.

82 This is especially extreme in light of the way in which the "in-line" price was reached. Present field prices for gas were assumed to be proper. However, a "suspect price doctrine" led to the exclusion from this norm of any prices as high as those being questioned before the courts or the Commission as excessively high. Thus a price was found to be "out of line" not only by being as high as some insupportable rate, but by being as high as one that some intervenor had chosen to call into question. Natural Gas Act $\$ 19$ (b), 52 Stat. 831 (1938), as amended, 15 U.S.C. §717r(b) (1964), makes such intervention rather easy. The Callery decision also compelled the producers to give refunds of monies collected beyond the "in-line" rate. 382 U.S. at 229-30. Thus not even a subsequent determination of a higher just and reasonable rate could help the producers as to rate payments made before that determination.

83 United Gas Improvement Co. v. Callery Properties, Inc., 382 U.S. 223, 227-28 (1965); Atlantic Ref. Co. v. Public Serv. Comm'n, 360 U.S. 378, 392 (1959) (Catco). 84382 U.S. at $228 ; 360$ U.S. at 392.

85 Area Rate Proceeding (Permian Basin Area), Utility Law Report No. 689, at 1 (FPC Aug. 5, 1965).

${ }^{86}$ Area Rate Proceeding (South Louisiana Area), 25 F.P.C. 942 (1961).

87382 U.S. at $227-28$. 
extreme variance in profit returns among efficient producers would seem to preclude all the rates' being just and reasonable. If the 1960 producer is not receiving a just and reasonable rate or if, indeed, the 1947 producer is receiving an unconscionable one, the rates should be determined by a standard responsive to the annual costs of the reasonably efficient producer.

\section{Relaxed Supervision of Small Producers}

The Permian hearing examiner had come to the conclusion that regulation of each and every producer was time-consuming and unnecessary. Of the hundreds of producers selling in the Basin, "fewer than 50 of them, each with national annual jurisdictional sales of over 10 million Mcf., [thousand cubic feet] sell 94 percent of the jurisdictional gas sold in Permian. Nationally some 75 large producers make 82 percent of the national jurisdictional sales." 88 Further, the position of the small independent producer would not seem to be such as to encourage him to be the source of increases in rates as a price leader.

The examiner's solution was to exempt all producers selling less than ten million Mcf. annually from any filing requirements other than an annual statement showing that sales were below that amount. The small producer, the examiner advised, should receive a blanket certificate of public convenience and necessity for all sales in the area ${ }^{89}$

But while such an exemption would be of great aid to the Commission's docket problem, it would serve to promulgate a fiction. As to original sales of gas, the examiner's recommended treatment seemed to constitute an unfounded declaration that all such future transactions, so long as the small producer kept within the quantitative limits, would satisfy the "public convenience and necessity." 90 As to section 4 rate increases, the small producer could theoretically raise his rates under the act without limitation and still have those rates characterized as "just and reasonable." ${ }^{01}$ The examiner had not made any special provision, with or without hearing, for insuring that the small producer's rate would not surpass the area ceiling. As to all producers, he had recommended invalidating favored nation clauses retroactively, ${ }^{32}$ and this at least would have avoided the triggering

88 Permian Area Rates, No. AR61-1, FPC, Sept. 17, 1964, pp. 145-46 (Examiner's decision).

89 Id. at $148-49,181$.

90 Natural Gas Act $\$ 7$ (c), 52 Stat. 824 (1938), as amended, 15 U.S.C. $\$ 717 f(c)$ (1964), quoted in note 9 supra.

91 Natural Gas Act $\$ 4(a), 52$ Stat. 822 (1938), 15 U.S.C. $\$ 717 c(a)$ (1964):

(a) All rates and charges made . . by any natural-gas company . . in connection with the transportation or sale of natural gas subject to the jurisdiction of the Commission, and all rules and regulations affecting . . . such rates or charges, shall be just and reasonable . . .

92 Permian Area Rates, No. AR61-1, FPC, Sept. 17, 1964, pp. 176-77 (Examiner's decision). 
effect of increases above the ceiling.93 The Commission, however, having concluded that the favored nation clauses should not be abolished except prospectively, ${ }^{94}$ felt that it must be able to limit the small producer's pricing activities to the same extent it controlled those of the large.

The Commission pointed out:

The impact of small producer prices on consumers is by no means de minimis on an area basis, and is of great impact in some situations. Sales by small producers constitute 80 percent of the gas supply of one pipeline and range from 9 percent to about 60 percent of the supply of the other 25 largest pipelines. While small producers represent only 15 percent of the aggregate interstate gas supply it is obvious they are a substantial factor in the cost of the gas supply of millions of American consumers.

Another consideration which weighs with us is that penetration of rate ceilings, even on a small scale, could be seriously disruptive of a pattern of uniform area ceilings. ${ }^{95}$

The Commission therefore modified the examiner's disposition. Concurrently with Permian it issued a rule that small producers would receive "small producer certificates," under which sales at a rate not in excess of the area ceiling need not be reported to the Commission. ${ }^{96}$ Section 4 increases would be handled the same way. ${ }^{97}$ Existing gas contracts, like all Permian agreements, were to be adjusted downward to the area limits if necessary, ${ }^{98}$ and pending applications were to warrant certificates conditioned upon "acceptance of an initial price no higher than the ceiling." 99 Initiation of rates in excess of the ceiling would require individual Commission approval ${ }^{100}$ to the same extent that this was required for large producers. ${ }^{101}$

The solution seems far more sensible and helpful to the Commission's goals than does the examiner's approach. There remains,

93 Whether the absence of triggering would have meant any lessening in the actual number of increases sought is difficult to say. Certainly the producer retains his right to seek an increase under such a system; he simply is not allowed to agree upon it with the pipeline at the time of initial contracting. See note 114 infra and accompanying text.

94 Area Rate Proceeding (Permian Basin Area), Utmity Law Report No. 689, at 126 (FPC Aug. 5, 1965).

$95 \mathrm{Id}$. at 122 .

$80 \mathrm{Id}$. at 124-25.

97 Id. at 125 . Section 4 (d) of the act specifically permits Commission waiver of the rate increase filing requirement in its discretion. Natural Gas Act $\$ 4$ (d), 52 Stat. 824 (1938), 15 U.S.C. \& 717c(d) (1964).

98 Area Rate Proceeding (Permian Basin Area), Utulty Law Report No. 689, at 124 (FPC Aug. 5, 1965).

99 Id. at 130.

$100 \mathrm{Id}$. at 125 .

101 Id. at 113-14. 
however, the question whether the special treatment of small producers is within the Commission's power under the Natural Gas Act.

To say that any and all small producer rates will automatically be "just and reasonable" seems indeed to be an expansive interpretation of the act's provision that "for the purposes of its rules and regulations, the Commission may classify persons and matters within its jurisdiction and prescribe different requirements for different classes of persons or matters." 102 Obviously the Commission's resolution fits within this rubric more easily than did the suggestion of the examiner. But it is not obvious from the words of the act that even the Commission's choice will be allowable.

As precedent for the Commission's power to decline meaningful jurisdiction over some producers, the examiner noted its unchallenged exemption of "percentage producers." 103 The comparison is wide of the mark. That exemption applies only to sales by a producer "to the operator of a processing plant at a price which is a percentage of the proceeds from the resale of the residue gas . . . ."104 The reason given in the regulation itself is that the processor-reseller is himself bound to file for a section 7 certificate. ${ }^{105}$ The actual sale for resale in commerce is thus regulated, and regulating the original producer's price would be mere duplication. At the time he sells his gas to the processor he either has no price, but only a percentage of a price undetermined as yet, or, if the processor is already operating under a section 7 certificate, a percentage of a price which the Commission has already approved. How great a percentage the producer attracts is irrelevant to the resale price's effect on commerce. ${ }^{108}$ The exemption of the percentage producer is thus of little aid to the examiner's position that the small producer can be given special treatment amounting to exemption from regulation.

Nevertheless, the logical relationship of the proposed treatment to the Commission's solution of its regulatory problem seems to assure its success in the courts; indeed, the Supreme Court has so suggested. Another agency, the National Labor Relations Board, has long refused jurisdiction over time-consuming matters that are of negligible effect on interstate commerce. The Board has gone so far, without benefit

102 Natural Gas Act $\$ 16,52$ Stat. 830 (1938), 15 U.S.C. § 717o (1964).

103 Permian Area Rates, No. AR61-1, FPC, Sept. 17, 1964, p. 146 (Examiner's decision).

10418 C.F.R. $\$ 154.91(\mathrm{e})$ (1961).

105 Ibid.

106 Of course, the argument can be made that such a price is no more or less relevant than is that of the normal producer, which is also, strictly speaking, prior to the gas' actual sale in interstate commerce. But the price here involved is only a percentage of a future price. Further, the Commission seems to retain the same quantum of effective jurisdiction, i.e., control of the sale immediately prior to the actual interstate sale. Since the reseller must process the gas to make it marketable in commerce, the percentage producer might better be compared with a provider of supplies or raw materials than with the normal producer. 
of any enabling statute, as to promulgate dollar volume minima below which jurisdiction over a business' controversy will not attach. ${ }^{107}$ Supreme Court approval of both the Board's and the Commission's regulations seems to have been rendered a certainty by the Court's dictum in FPC v. Hunt: ${ }^{108}$

Procedures must be worked out, not only to clear up this docket congestion, but also, to maintain a reasonably clear current docket so that hearings may be had without inordinate delay. In this connection the techniques of the National Labor Relations Board might be studied with a view to determining whether its exemption practices . . . might be helpful in the solution of the Commission's problems. ${ }^{109}$

In such a circumstance it seems that even the examiner's solution would have been sustained under the act. The Commission's solution combines the best features of exemption and regulation, cutting down unnecessary docket congestion and thereby saving both small producers and the public substantial expense, while insuring the integrity of the area ceiling and, in fact, affirmatively encouraging small producers' staying within the ceiling's limits.

\section{The Moratorium: Casting Out the Section 4 Devils}

The fact that Permian, which was "conducted with acute awareness of the running of time," 110 was over four and one-half years in completion before reaching court review indicates the probable truth of the statement that section 5 "just and reasonable" hearings are "inherently time-consuming proceedings." 111 For this reason the Commission sought to preserve the integrity of its new rate ceilings by the imposition of a two and one-half year moratorium, terminating in 1968, on section 4 rate increase filings:

In the absence of such a moratorium the producers would be free to file rate increases and continue to collect their producer prices even though they exceeded the just and reasonable rates herein prescribed. Without a moratorium, the conclusion of one area proceeding would only signal the beginning of the next, and just and reasonable rates for consumers would always be one area proceeding away. . . . Without the moratorium we have provided the public interest could be protected only to the extent that the Commission

107 See Guss v. Utah Labor Relations Bd., 353 U.S. 1, 3-4 (1957).

108376 U.S. 515 (1SC1).

109 Id. at 527.

110 Area Rate Proceeding (Permian Basin Area), Utmity Law Raport No. 689, at 109 (FPC Aug. 5, 1965).

111 Ibid. Compare text accompanying note 84 supra. 
could devise procedures to enable it to complete an area proceeding within the 5 -month suspension period or shortly thereafter. ${ }^{112}$

Certainly this is true. The Commission's regulatory problems have sprung in large measure from the flimsiness of section 4's bastions. ${ }^{113}$ The special treatment of small producers will mitigate this problem. Accepting the hearing examiner's recommendation that favored nation clauses be retroactively barred would have helped, too, ${ }^{114}$ but the favored nation proscription would work only to limit the parties' rate agreement at the time of original filing; it would not prevent the producer and the pipeline from later agreeing to an increase and, hence, a filing and rate increase under section 4 . The refund provision of section 4 is famous for its inadequacy to the task of consumer protection. The refund money is tied up indefinitely, during which time the consumer may well have changed his residence. The consumer's distributor may not be bound by local law to return him his money in any case, but only to reflect the windfall in its own rates. Meanwhile, there is inevitable expense in the money's being filtered up through the gas commerce chain and then back down again. ${ }^{115}$ Finally, even absent any "triggering" effect on federally regulated sales, a high rate will tend to splash over into unregulated intrastate commerce, pushing the entire market up unnecessarily. ${ }^{118}$ But the question remains whether the Commission's obvious need for a moratorium justifies reading the producer's section 4 right to increase his rates out of the act.

Despite wording that appears obvious, section 4 can perhaps be read as conveying something less than an absolute right to increase rates subject only to the Commission's short staying and refund conditioning power. The Commission in Permian ${ }^{117}$ adverted to the Supreme Court's remark that the section "says only that a change cannot be made without the proper notice to the Commission; it does not say under what circumstances a change can be made." ${ }^{118}$ That statement, however, was made with reference to a producer's application for an increase in derogation of his contract with a pipeline and would not seem to shed any light on the Commission's power to

112 Id. at 108.

113 See text accompanying notes 10-12 supra.

114 Such clauses have been barred in new certification application contracts since 1961-62. 18 C.F.R. $\$ 154.93$ (1962). The Commission's power to reject, without a hearing, applications containing such clauses was upheld in FPC v. Texaco, Inc., 377 U.S. 33 (1964).

115 See FPC v. Tennessee Gas Transmission Co., 371 U.S. 15455 (1962); 112 U. PA. L. REv. 909, 913 (1964).

116 See FPC v. Texaco, Inc., 377 U.S. 33 (1964) ; FPC v. Hunt, 376 U.S. 515, 524-25 (1964).

117 Area Rate Proceeding (Permian Basin Area), Utrity LAw Report No. 689, at 110 (FPC Aug. 5, 1965).

118 United Gas Pipe Line Co. v. Mobile Gas Serv. Corp., 350 U.S. 332, 339 (1956). 
limit section 4. The Commission seems, however, to have taken the position that it is capable of as high a degree of control over rate increase privileges, up to and including absolute prohibition, as are the bargaining parties themselves:

It is our view that the filing of rate increases . . . can be limited either by private contract or as a result of the reasonable exercise of this Commission's authority under Sections 5, 7 and 16 of the Act. Certainly, it would be an anomalous situation if the filing of rate increases could be restricted by private bargaining but not by reasonable exercise of regulatory authority in the public interest. ${ }^{119}$

But while it may readily be conceded that the situation is either anomalous or anachronistic or, probably, both, Congress, which certainly had the option of placing increase filings under the same unlimited Commission staying powers as it did original certificate requests, ${ }^{120}$ seems deliberately to have chosen this pattern. Obviously the provision is a poor choice by Congress, but it is Congress' choice nevertheless.

The Commission found power to prevent filings above the area ceiling in its section 5 authorization to set a just and reasonable rate, practice or contract "to be thereafter observed and in force," ${ }^{21}$ and in section 16, by which it can issue orders "necessary or appropriate to carry out" the act's provisions. ${ }^{122}$ It supported its conclusion ${ }^{123}$ with several Interstate Commerce Commission decisions ${ }^{124}$ under the Hepburn Act and a Supreme Court decision, United States $v$. Corrick, ${ }^{125}$ involving the Packers and Stockyards Act. While the statutes involved in those cases are similar to provisions of the Natural Gas Act, both provide for the agency's establishing maximum, not merely "just and reasonable," rates. ${ }^{126}$ Each also provided that once a maximum provision had been set, the regulated party should not

119 Area Rate Proceeding (Permian Basin Area), Utmity LAw RepoRt No. 689, at 109 (FPC Aug. 5, 1965).

120 Compare note 9 supra and accompanying text, with note 10 supra and accompanying text.

121 Natural Gas Act $\S 5$ (a), 52 Stat. 823 (1938), 15 U.S.C. $\$ 717 d(a)$ (1964), quoted note 80 supra.

122 Natural Gas Act $\S 16,52$ Stat. 830 (1938), 15 U.S.C. §717o (1964).

123 Area Rate Proceeding (Permian Basin Area), Utmity LAw Report No. 689, at 111-12 (FPC Aug. 5, 1965).

124 E.g., City of Springfield v. Louisville \& N.R.R., 53 I.C.C. 603 (1919).

125298 U.S. 435 (1936).

126 Interstate Commerce Act of 1906 (Hepburn Act) $\$ 4,34$ Stat. 589, as amended, 49 U.S.C. \$15(1) (1964) :

[T] he Commission is authorized ... whenever, after full hearing upon a complaint . . . it shall be of the opinion that any of the rates ... demanded, charged, or collected ... are unjust and unreasonable ... to determine and prescribe what will be the just and reasonable rate ... to be thereafter 
publish or collect any higher one. ${ }^{127}$ A power to set a maximum rate implies an impenetrable ceiling; not so the case of the "just and reasonable" rate. Further, far from these specific grants of power, section 16 of the Natural Gas Act seems to have been intended only to enable the Commission to run its own office in an efficient manner, and not to add to the substance of its power over regulated parties. ${ }^{123}$

Yet the FPC's acting to limit the availability of section 4's comforts is neither a new nor a wholly untested device. Pipeline certificates have been conditioned on the acceptance of a moratorium on rate increases as early as $1939 .{ }^{129}$ Further, the Supreme Court's Catco ${ }^{130}$ decision attested to the Commission's power to exert influence upon the contractual arrangements of the parties by the imposition of certificate conditions. Following Catco the Court has three times upheld such conditions limiting the producer's resort to section 4.

observed . . and to make an order that the carrier shall cease and desist from such violation . . . and shall not thereafter publish, demand, or collect any rate . . . in excess of the maximum rate . . . so prescribed . . . .

Packers and Stockyards Act $\$ 310,53$ Stat. 1351 (1939), 7 U.S.C. $\$ 211$ (1964):

Whenever after full hearing . . . the Secretary is of the opinion that any rate... [is or will be] unjust [or] . . . unreasonable . . . the Secretary-

(a) May determine and prescribe what will be the just and reasonable rate ... to be thereafter ... observed ... as both the maximum and minimum to be charged ... and

(b) May make and order that such . . . operator

(1) shall cease and desist from such violation ...

(2) shall not thereafter publish, demand, or collect any rate

... more or less than the rate or charge so prescribed . . . .

127 Ibid. These provisions speak only to the maximnm rate, not the just and reasonable one. As to the latter, the acts provide only that, as in the case of the Natural Gas Act, it is "to be thereafter observed." The Hepburn Act, which is $\$ 2$ of the Interstate Commerce Act of 1906, 34 Stat. 586, as amended, 49 U.S.C. $\$ 6$ (1964), also requires that notice be given to the Commission before the initiation of a new rate, and grants the Commission unlimited staying power pending approval of the rate. 34 Stat. 586 (1906), as amended, 49 U.S.C. \& 6(3) (1964). The Packers and Stockyards Act $\$ 306$ (e), 42 Stat. 164 (1921), 7 U.S.C. $\$ 207$ (e) (1964), like the Natural Gas Act, gives the Commission only a limited staying power after notice. It may be that the Hepburn and Packers and Stockyards Acts differ from the Natural Gas Act in having a dual function, that of setting maximum "ceiling" rates, and that of adjudicating the justness and reasonableness of the rates within that circumscription. One commentator has said:

Since under the Natural Gas Act, there is only one kind of rate, just and reasonable for the case, and since Corrick was as a matter of fact dealing with the other kind of rate, a set maximum, its relevance is questionable.

Comment, 54 Gro. L.J. 713, 717 n.30 (1966).

128 Natural Gas Act $\$ 16,52$ Stat. 830 (1938), 15 U.S.C. $\$ 7170$ (1964):

The Commission shall have power to perform any and all acts, and to prescribe, issue, make, amend, and rescind such orders, rules, and regulations as it may find necessary or appropriate to carry out the provisions of this chapter. Among other things, such rules and regulations may define accounting, technical, and trade terms used in this chapter; and may prescribe the form or forms of all statements, declarations, applications, and reports to be filed with the Commission, the information which they shall contain, and the time within which they shall be filed.

129 See Louisiana-Nevada Transit Co., 2 F.P.C. 546, 549 (1939).

130 Atlantic Ref. Co. v. Public Serv. Comm'n, 360 U.S. 378 (1959) (Catco). 
One situation involved the 1961-1962 orders forbidding favored nation clauses in new contracts filed under section 7.131 There the Court upheld the Commission's right to reject, without a hearing, an application containing such clauses. ${ }^{132}$ That case, however, is of questionable weight in supporting the imposition of a condition which totally forecloses the producer's access to section 4 for any period of time. The rule against favored nation clauses does not limit the producer's right to request a rate increase; as previously, he may seek the increase with the pipeline's approval. All the rule demands is that the agreement be reached when the producer and the pipeline feel it is merited, and not in advance of the original sale. The decision is further weakened as support for the Commission's action by its reliance on precisely the proposition that the Commission now attempts to deny, i.e., that the producer has a plenary right to file section 4 increases:

It must be remembered that under this Act rate increases are initiated by the natural gas company, the Commission having the burden by reason of $\S 4(\mathrm{e})$ of the Act to initiate a hearing on their legality with only a limited power to suspend new rates. ${ }^{133}$

The Supreme Court did, however, uphold a moratorium on section 4 increases in FPC v. Hunt. ${ }^{134}$ Reversing the Court of Appeals for the Fifth Circuit, ${ }^{135}$ the Supreme Court upheld the Commission's right to condition the granting of a temporary certificate under section 7 (c) upon producer agreement not to file rate increases until a permanent section 7 certificate should be granted. Section 7 (c) provides:

[T] he Commission may issue a temporary certificate in cases of emergency, to assure maintenance of adequate service or to serve particular customers, without notice or hearing, pending the determination of an application for a certificate ....136

The function of the temporary certificate is thus to allow gas to be sold while the time-consuming section 7 procedure is in process. The 7 (c) certificate is clearly not dispositive of anyone's rights but is a stopgap expedient, designed only to facilitate the bringing of

131 See note 114 supra.

132 FPC v. Texaco, Inc., 377 U.S. 33 (1964).

133 Id. at 42.

134376 U.S. 515 (1964).

135 Hunt v. FPC, 306 F.2d 334 (5th Cir. 1962). (1964).

136 Natural Gas Act $\$ 7(c), 52$ Stat. 824 (1938), as amended, 15 U.S.C. $\$ 717 f(c)$ 
gas into commerce in the discretion of the Commission. The Court weighed these characteristics heavily:

When the independent producer knocks on the door of the Commission for permission to enter his gas in interstate commerce he must submit to the requirements of $\S 7$. His natural gas must be certificated before it can move into interstate commerce. If he wishes to avoid the delay incident to a hearing for a permanent certificate he may apply for temporary authorization, which may be granted upon ex parte application. In view of this, the Commission must have the authority to condition a temporary certificate so as to avoid irreparable injury to affected parties. This condition, once imposed, continues only during the pendency of the producer's application for a permanent certificate. In view of the ex parte nature of the proceeding, it appears only fair to all concerned that the condition upon which the rate was temporarily certified be continued unchanged until the permanent certificate is issued..$^{137}$

The existence of broad discretionary power in the Commission to condition temporary certificates appears to us to be vital to its ability to hold the line in pricing. The extent of that power in permanent certification is not before us now ... 138

Two Justices dissented on the theory that poor legislative judgment was being replaced by legislative judging. ${ }^{139}$ But the case for the temporary certificate moratorium is a good one. The producer, pending certification, has no right to sell his gas. He does have the option of refusing temporary certification without prejudice to his application. ${ }^{140} \mathrm{He}$ should not in fairness be allowed to accept a temporary discretionary certificate and then attack the conditions to which it has been subjected.

This reasoning led the Fifth Circuit to distinguish Hunt when, in Callery Properties, Inc. v. FPC, ${ }^{141}$ it confronted a moratorium upon a permanent certificate. Here, however, the moratorium itself was temporary. The producers' receipt of permanent certificates had been

137376 U.S. at 523.

$138 \mathrm{Id}$. at 526.

$139 \mathrm{Id}$. at 527.

140 See Atlantic Ref. Co. v. Public Serv. Comm'n, 360 U.S. 378, 387-88 (1959) (Catco). Catco's facts clearly indicate that the producers had suffered no prejudice to their permanent certificate application, despite their having twice refused temporary certification at a lower rate.

141335 F.2d 1004 (5th Cir. 1964). 
reversed ${ }^{142}$ in light of the Catco "in-line" doctrine. On remand in 1963 the Commission set new, lower rates according to the area "guidelines." ${ }^{143}$ The in-line price was to be maintained without section 4 increase until termination of the South Louisiana area proceeding or July 1, 1967, whichever was earlier. The court of appeals held that such a condition was beyond the power of the Commission. ${ }^{144}$

On certiorari the Supreme Court reversed, ${ }^{145}$ citing Hunt:

We noted in [Hunt] . . . that "a triggering of price rises often results from the out-of-line initial pricing of certificated gas" and that the possibility of refund does not afford sufficient protection. . . . [T] here was ample power under $\S 7$ (e) for the Commission to attach these conditions for consumer protection during this interim period though the certificate was not a temporary one . . . but a permanent one, as in CATCO ......$^{146}$

Mr. Justice Harlan's opinion, concurring in part, is more specific:

Recognizing force in the contrary view of the Court of Appeals, I do not believe that $\S 4$ must be read to bestow on producers an invincible right to raise prices subject only to a six-month delay and refund liability. . . . A freeze until 1967 is not permanent price fixing, and in this interregnum between individual and area pricing, the hazard of irreversible price increases warrants imposing some brake. ${ }^{14 \tau}$

Callery is substantially stronger authority for the Commission's Permian moratorium than is Hunt. Not only was the Callery stay imposed upon a permanent certificate, but that stay was imposed after the initiation of service. The producers had been given permanent section 7 certificates at a certain rate. After their acceptance of the certificates, and the passage of the time in which they had the option

142 The reversals took place in the Supreme Court and in several of the circuit courts. Public Serv. Comm'n v. FPC, 361 U.S. 195, vacating per curiam United Gas Improvement Co. v. FPC, 269 F.2d 865 (3d Cir. 1959) ; United Gas Improvement Co. v. FPC, 290 F.2d 147 (5th Cir.), cert. denied sib nom. Superior Oil Co. v. United Gas Improvement Co., 366 U.S. 965 (1961) ; United Gas Improvement Co. v. FPC, 290 F.2d 133 (5th Cir.), cert. denied sub nom. Sun Oil Co. v. United Gas Improvement Co., 368 U.S. 823 (1961); United Gas Improvement Co. V. FPC, 287 F.2d 159 (10th Cir. 1961) ; Public Serv. Comm'n v. FPC, 287 F.2d 146 (D.C. Cir. 1960), cert. denied sub nom. Hope Natural Gas Co. v. Public Serv. Comm'n, 365 U.S. 880 (1961); United Gas Improvement Co. v. FPC, 283 F.2d 817 (9th Cir. 1960), cert. denied sub nom. Superior Oil Co. v. United Gas Improvement Co., 365 U.S. 879 (1961).

143 Placid Oil Co., 30 F.P.C. 283 (1963). The guidelines had been promulgated to "hold the line" pending the determination of proper area rates in Permian and its kin. Statement of General Policy No. 61-1, 24 F.P.C. 818 (1960).

144 Callery Properties, Inc. v. FPC, 335 F.2d 1004 (5th Cir. 1964).

145 United Gas Improvement Co. v. Callery Properties, Inc., 382 U.S. 223 (1965). 146 Id. at 228-29. (Emphasis added.)

147 Id. at 232 . 
of accepting or rejecting them, the certifications were appealed. ${ }^{148}$ In 1965 , the original certificates were reconditioned at a substantially lower price and the producers, without option of withdrawing their gas and selling it intrastate, ${ }^{149}$ were ordered not to raise their rates for a period of time. It would thus seem that any argument by a Permian producer that a moratorium cannot be imposed upon existing certificates under any circumstances has been foreclosed.

Further, the Commission took pains in Permian to insure that no producer will be forced to sell his gas at a rate lower than cost. Claims of confiscation may be filed and, upon hearing, the Commission will either allow abandonment of the service or, perhaps, in extreme cases, allow adjusting of the rate above the area ceiling. ${ }^{150}$ To this extent the Commission's Permian disposition is more solicitous of producer interests than was that of Callery.

But Callery, like Hunt, places great stress on the fact that the moratorium is being imposed only temporarily and will be lifted upon the Commission's impending determination of a proper rate. In Hunt this determination is the "public convenience and necessity" hearing of section 7; in Callery the Court goes further, saying that, in light of the proved impossibility of a full dress section 7 hearing without substantial docket congestion, the producers must abide a Commission determination of "just and reasonable" rates in the section 5 area proceeding. Both cases stressed the fact that proper rates would be found ${ }^{151}$ and that, probably more important, only a temporary "suspension" of the producer's section 4 privileges would allow such a finding at a reasonable time. ${ }^{152}$ The Permian moratorium does not meet the first test employed in these decisions. Here the just and

148 Under the statute a party is allowed sixty days in which to appeal the Commission's disposition of a matter. Natural Gas Act $\S 19$ (b), 52 Stat. 831 (1938), 15 U.S.C $\$ 717 \mathrm{r}$ (b) (1964). Yet, by Commission regulation, 18 C.F.R. $\$ 157.20(\mathrm{a})$ (1961), a proffered certificate will be deemed rejected unless accepted within thirty days. In Callery the appeal had not been filed until after the first thirty day period. One producer argued before the Fifth Circuit that had it known an appeal would be taken, it would not irrevocably have dedicated its gas to interstate commerce. Brief for Petitioner Superior Oil Co., p. 42, Callery Properties, Inc. v. FPC, 335 F.2d 1004 (5th Cir. 1964). Of course, such a change of rate after final dedication is always to be anticipated, by way of a $\$ 5$ "just and reasonable" hearing.

149 The ability to abandon service is narrowly circumscribed under the act:

No natural-gas company shall abandon all or any portion of its facilities subject to the jurisdiction of the Commission, or any service rendered by means of such facilities, without the permission and approval of the Commission first had and obtained, after due hearing, and a finding by the Commission that the available supply of natural gas is depleted to the extent that the continuance of service is unwarranted, or that the present or future public convenience or necessity permit such abandonment.

Natural Gas Act $\S 7$ (b), 52 Stat. 824 (1938), 15 U. S. C. \$717f(b) (1964).

150 See Area Rate Proceeding (Permian Basin Area), Utrlity Law Report No. 689, at 104-06 (FPC Aug. 5, 1965).

151 United Gas Improvement Co. v. Callery Properties, Inc., 382 U.S. 223, 228-30

(1965) ; FPC v. Hunt, 376 U.S. 515, 523-24 (1965).

152 Ibid. 
reasonable rate has already been determined; that is what the proceeding was all about.

Callery and Hunt would certainly offer no support to a permanent moratorium on section 4 rate increases. Further, it seems clear that they would not support a temporary moratorium without a rationale. The cases seem to require that some regulatory emergency exist which makes the holding of increase filings in abeyance a necessity. Further, it should not be enough that the Commission has a problem; the moratorium must contribute to the final solution of that problem rather than as a mere postponement device. The Permian opinion offers no hint as to what this problem might be.

It is clear that, absent a moratorium, the Commission may continue to have docket problems. ${ }^{153}$ But, insofar as the Permian Basin is concerned, none of these problems will be cured by imposition of a moratorium; they will only be held at bay for a while. Permian has already regulated the rates of all flowing gas in the Basin. Thus the only contributions to the docket snarl coming from that area would seem to be initial certification proceedings and section 4 increase filings. These types of proceedings, however, will presumably still be around in 1968. But these are the only problems to which the opinion adverts. ${ }^{154}$

There is, of course, one view under which the moratorium could be characterized as being of the temporary type allowed in Callery and Hunt, i.e., one which contributes to the solution of a temporary Commission regulating problem. Permian sets the just and reasonable rate for only one part of the nation. It is conceivable that rate increase filings in the Permian Basin might be more likely to contribute to docket havoc today than they would in 1968 because several other rate proceedings are pending ${ }^{155}$ and some individual certification and rate increase applications are in progress throughout the non-Permian producing areas. ${ }^{150}$ In such a situation the Permian moratorium might be sustainable. However, as each succeeding rate proceeding eliminated its share of docket problems, moratoria would become less allowable and, ultimately, insupportable. But nowhere in its opinion does the Commission mention the non-Permian docket pressures as contributing to its conclusion that a moratorium is necessary. It is thus hard to characterize this problem as the moratorium's moving cause. Further, since the Commission offers no findings of fact as to

153 See text accompanying note 112 stpra.

164 Ibid.

155 Area Rate Proceeding (Hugoton-Anadarko Aŕea), 30 F.P.C. 1354 (1963); Area Rate Proceeding (South Louisiana Area), 25 F.P.C. 942 (1961). These proceedings, along with Permian, are expected to set area rates covering $75 \%$ of the gas flowing in interstate commerce. Area Rate Proceeding (Permian Basin Area), UTIIITY LAW REPORT No. 689, at 10 (FPC Aug. 5, 1965).

156 For example, the applications involved in Callery had been severed from the South Louisiana area proceeding docket in the interests of expedience. United Gas Improvement Co. v. Callery Properties, Inc., 382 U.S. 223, 226 (1965). 
whether non-Permian section 7 and 4 proceedings make the moratorium necessary, a reviewing court would seem to have no way of telling whether the stay is justified under the operant facts.

At the same time, the Commission provides itself with an alternative, one which gives an inkling that what is actually planned is indefinite limitation of the producer's access to section 4 . The area ceiling is not to be passed before January 1, 1968

unless within such time, either upon the Commission's own motion or upon an adequately supported petition by some interested party, the Commission at its discretion decides to reopen this proceeding to consider whether a different rate . . . should be adopted for sales certificated at subsequent periods. ${ }^{\mathbf{1 5 T}}$

It is not unreasonable to apprehend that the Commission might intend to establish a pattern of imposing a moratorium, occasionally reopening the area proceeding, adjusting the rate and imposing a new "temporary" moratorium at a slightly higher ceiling. Perhaps under such a system the producer would ultimately fare no better or worse than under the statutory procedure of section $4 .{ }^{158}$ Nevertheless it would seem to be as much a Commission amendment of the act as a permanent moratorium would be. In either case section 4 is effectively circumscribed within the Commission's discretion. The producer's right to initiate a new rate would be permanently limited to those rates bearing the Commission's imprimatur. Such a scheme would be better for the consumer, ${ }^{159}$ but that is not the way Congress wrote the act.

The reviewing court must therefore be extremely careful to plumb the real nature of this Permian moratorium. If its function is merely to form the first link in a permanent chain of temporary stays, tied together by occasional updatings of the ceiling, it should be reversed as an administrative attempt at statutory amendment. If, on the other hand, the basis for the Commission's imposition of the moratorium is the presence of other docket-crowding FPC activities, which are now a preemptive problem but will not be in 1968 by reason of the moratorium's clearing the decks, then perhaps the moratorium can be sustained. In that event the court will have the duty of satisfying itself-and a remand on this question might be necessary-that these soluble conditions do exist and will be mitigated to such an extent as to justify the moratorium. Further, the court should avoid considering those regulatory problems which spring not from a present soluble condition, but from the nature of the regulatory statute and

157 Area Rate Proceeding (Permian Basin Area), Utility LAw Report No. 689, at 113 (FPC Aug. 5, 1965).

158 This is so in light of §4's refund provision. Natural Gas Act $\S 4(e), 52$ Stat. 823 (1938), 15 U.S.C. \$717c(e) (1964),

159 See text accompanying notes 115-16 supra. 
the subject matter being regulated. Solution of these latter conditions lies not with the agency or the court but with Congress.

\section{CONCLUSION}

Each of the Commission's Permian innovations discussed in this Comment will, if upheld, play an effective role in protecting the long suffering consumer of natural gas. The area rating system will not only relieve the Commission of the docket congestion incidental to individual cost-of-service ratemaking, but will also guard against the initiation of service at rates that are too high because unduly profitable or based upon indefensible costs. Meanwhile, setting a future Gas Well Gas rate high enough will insure the future availability of gas to the interstate market. Relaxed supervision of small producers will clear the decks of largely unnecessary matters while encouraging small producer adherence to the rate ceilings. Both the producer's and the public's time and money will be saved. The moratorium, finally, will prevent the use of section 4 to initiate insupportable rate hikes pending determination on the merits. In the present posture of the record, however, only the special treatment of small producers seems clearly sustainable.

The two-price system, as effected by Permian, is insupportable; it puts the early gas producer's hand far too deep into the consumer's pocket. Probably, too, the producers of more recent years culminating in 1960 are being insufficiently compensated for their labors. Certainly the Permian scheme allows the profit percentage of the reasonably efficient producer to vary greatly depending upon when he found his gas. A court reviewing Permian should thus reverse this determination, demanding that if cost-based rates are to be utilized, the resulting rates must actually reflect the real costs of the producer of average industry efficiency for the year-or similar cost group of years-in which the gas was found. This disposition would also soften the indefensible chasm between the rates of the 1960 and 1961 producers. The Commission's defense that such annual determinations would be impossible finds no support in the record; that they would be difficult is no answer.

The temporary moratorium on section 4 rate increases is a different matter. Although the Commission has made a flimsy case in support of its power to impose such a moratorium, there is a possibility that the moratorium can be sustained. To be affirmed the Commission's record will require amplification on the question whether temporary docket congestion will be eliminated by reason of the moratorium. The condition giving rise to this congestion must itself be temporary, susceptible to remedy by the Commission, and must certainly not be that congestion growing out of the nature of section 4 itself. Even if such justification is found, however, the court should 
make it clear that post-area proceeding moratoria are allowable only until such time as non-area proceeding docket problems are substantially eliminated. If, on the other hand, no proof of such justification can be made, then the moratorium must be overturned. This, of course, might sap the vitality of the Commission's Permian rate determinations; perhaps just and reasonable rates always will be one area proceeding away. But the solution of that problem can come only from Congress. 


\section{APPENDIX}

Weighted Average Cost Index of Gas Weli Gas

Produced in 1960, United States $(1960=100)$

Table I

Index of Drilling and Equipping

Cost/Mcf Reserves Added

$\begin{array}{ccc} & \text { Dr. Foster } & \text { Dr. Joskow } \\ 1947 & 50.6 & \\ 1948 & 53.7 & 62.4 \\ 1949 & 55.6 & 61.0 \\ 1950 & 57.9 & 63.9 \\ 1951 & 62.2 & 70.7 \\ 1952 & 66.6 & 71.0 \\ 1953 & 70.6 & 90.7 \\ 1954 & 74.5 & 96.2 \\ 1955 & 78.5 & 107.8 \\ 1956 & 83.5 & 99.1 \\ 1957 & 90.3 & 91.8 \\ 1958 & 92.9 & 87.6 \\ 1959 & 97.5 & 91.8\end{array}$

Table II

Estimated Reserves of Gas Well Gas Added:

Percentage Contribution to 1960 Production

$\begin{array}{rcc} & \text { Dr. Foster } & \text { Dr. Joskow } \\ 1947 & 3.86 & \\ 1948 & 4.35 & 3.97 \\ 1949 & 4.19 & 3.63 \\ 1950 & 4.35 & 4.81 \\ 1951 & 5.01 & 4.50 \\ 1952 & 5.42 & 5.11 \\ 1953 & 8.23 & 8.15 \\ 1954 & 2.80 & 2.99 \\ 1955 & 9.41 & 6.76 \\ 1956 & 10.83 & 8.12 \\ 1957 & 8.75 & 8.60 \\ 1958 & 8.00 & 9.23 \\ 1959 & 8.09 & 8.04 \\ 1947-59 & 83.29 & 73.91\end{array}$

